\title{
Technological Change: A Central yet Neglected Feature of Public Administration
}

\author{
Christopher Pollitt
}

\begin{abstract}
This overview paper has two aims. The first is to indicate that technological change has been a somewhat neglected, or at the least esoteric, topic within the academic field of public administration. The second is to argue that this neglect is damaging for the PA community, because technological change is actually fundamental to developments in public administration, in a variety of ways.

In order to demonstrate these two points, a wide range of literature is called upon, across many sectors.

In conclusion a framework is offered to encourage the kinds of analysis of technological change that should ensure strong links with the central concerns of public administration scholarship.
\end{abstract}

\section{Introduction}

"If the experience of modern society shows us anything...it is that technologies are not merely aids to human activity, but also powerful forces acting to reshape that activity and its meaning." (Winner 1986, 6)

The central argument of this paper is that technological change is a powerful shaping influence on public administration, but one which is seldom directly addressed by most public administration scholars. The paper sets out a spectrum of ways in which - to parallel Langdon Winner's words - technological change in the public sector changes activities and changes meanings. In doing so it also offers a broad set of conceptual categories which can be used to analyze the processes of technological evolution. 


\section{The neglect of technology in public administration scholarship}

Few if any of the major works on public administration and public management published over the past decade give prominence or explicit space to "technology" (e.g. Bovaird and Löffler 2009; Christensen and Lægreid 2007; Ferlie et al. 2005; Kickert 2008; Hood 1998; Osborne 2010; Pollitt and Bouckaert 2004). Indeed in many PA books, the term does not even appear in the index, or, if it does, then only in connection with information and communication technologies (ICTs).

Of course this does not mean that technological change has been totally ignored. While the majority of scholars proceed with their usual business, making few, if any references to technological change, alongside them, a specialist minority have long focused on "e-government" and "e-governance" (e.g. Bekkers and Homburg 2005; Bellamy and Taylor1998; Fountain 2001; Snellen and Van de Donk 1998). Some of these works have certainly generated useful theories and/or conceptual frameworks. Taken as a whole, however, there are two important limitations to this work. The first is that, very important though ICTs are, they are far from being representative of the full spectrum of technologies to influence public administration (as we shall see a little later). The second is that communications between this pioneering minority of e-government enthusiasts and the majority have been limited. It is only recently that a few mainstream scholars have begun to accommodate e-government issues within the central ideas and frameworks of the field (e.g. Dunleavy et al. 2006; Hood and Margetts 2010). This "ghetto-ization" of e-government has been noted by a number of observers (Hood and Margetts 2010; Lips and Schuppan 2009), and was described by Dunleavy et al. as "theoretical neglect" $(2006,9)$.

There is another way of identifying the relative neglect of technology in academic public administration - a less scholarly but more direct way. The reader can simply ask him-/herself how often the recent public administration writing they are familiar with engages with - to take a small sample - technologies for greenhouse gas emission reduction, or for the application of genetics in medical care, or for mobility for the disabled, or for sub-lethal weaponry for the police, or for the construction of high-speed mass-transit systems, or for domestic heating and insulation, or for the electronic archiving of government records, or for automatic facial recognition at borders or in any other public place, or for spatial data infrastructures, or (last but not least) for registering births, marriages and deaths? I suspect the answer is either "never" or "rarely". But now the reader should answer a second question: how do they assess the consequences of these technologies for the management of major public services and for government regulatory policies? My answer is "enormously important, and enormously complex". They will have major impacts on, inter alia, budgets, jobs, accountability and transparency, security and public order, efficiency, effectiveness and relations with citizens. 


\section{Defining technology}

Before going any further, it is necessary to try to define "technology". It is a large and plastic concept, and one could easily spend a lot of time probing its many definitions. That is not, however, the purpose of this paper, so I will shortcut by opting for a broad definition.

A distinction can be made between a technical device, conceived of as a material or immaterial artifact, and a technology, a concept which refers not just to a device in isolation but also to forms of knowledge, skill, diagrams, charts, calculations and energy which make its use possible (Barry 2001, 9 - original italics)

Note, therefore, that:

The idea that a non-human device or instrument can somehow work autonomously of its multiple connections with other (human and non-human) elements (language, bodies, minds, desire, practical skills, traditions of use) is a fantasy. (Barry 2001, 9)

Thus technologies are not just objects, divorced from human skills and relationships. Neither can technologies ever be entirely separated from politics (certainly not by handing them over to "experts", although for other reasons, that may be, at certain points, a sensible thing to do). They consist of assemblies of practices as well as components (Arthur 2009, 28-31). They are inextricably embedded in political, organizational and economic relationships. Bekkers and Homburg put it succinctly: "the introduction of ICT in public administration is a social intervention in a policy network, which influences the position, interests, values and (information) domains of the actors involved" $(2005,9)$. Winner, following Wittgenstein, even refers to technologies as "forms of life" (1986, 11-16).

\section{The relationship between technological change and organizational and political change: overview}

We can now turn to the central question - what is the relationship between technological change and administrative and political change? In this section, I will attempt to offer a short, general, theoretical answer. Subsequently, in the remainder of the paper, the question will be answered in a more extended, illustrative way by reference to a series of studies and examples.

There is, of course, a rather popular and direct answer to this question. It is, in essence, that technological change, by enormously increasing both the speed and the volume of communications and computations, has shrunk both space and time, and made them less important, while at the same time opening up the possibility of mass access to public decision-making. Such claims are usually followed by examples of 
how, if suitably equipped, one can now access vast amounts of data, 24/7, by mobile communication devices, and can communicate in real time with one or many similarly equipped persons anywhere in the world (or, for that matter, in "outer space"). The literature is also full of rather strident claims about what new technologies - usually ICTs - are going to do to politics and the public sector. Modern ICTs will undermine and sweep away bureaucractic hierarchies, say some enthusiastic commentators (e.g. Thompson and Jones 2008). Others see the internet as ushering in mass, participatory direct democracy (see Graham 1994, quoted in Bellamy and Taylor 1998, 110). My argument here will be that such "cyber-optimist" prescriptions are much too simple. Sometimes organizing will be much quicker and easier; sometimes hierarchies will be weakened; sometimes new forms of participation may flourish. Often, however, other things seem to get in the way of these simple visions - either delaying them or derailing them altogether. Quite frequently, far from revolutionizing the ways in which decisions pertaining to public affairs are taken, new technologies simply reinforce pre-existing patterns and divisions, such as those between those who are already civically active and those who are not (Norris 2001; Smith et al. 2009). The impact of technological change therefore varies with the particular activities under consideration, the institutional context and culture, legal rules and financial considerations, and many other factors. There is usually interaction - not a one-way flow - between these factors, so that each leaves their mark and none are simply determined by or dependent upon any of the others.

The theoretical literature exhibits a spectrum of theoretical positions, ranging from technological determinism (in which technological change drives organizational change) to a kind of cultural determinism (in which technologies have no independent force, but always depends on how they are interpreted in relation to local and current cultural norms and/or political priorities). Neither of these extremes seems tenable (Bellamy and Taylor 1988, 151-152; Borins et al. 2007; Winner 1986, 19-39). Neither does some of the socio-technical systems literature - full of worthy but distant abstractions - seem to be particularly useful for the examination of concrete government policies (e.g. Geels 2004). A first step, therefore, is to allow for an "emergent" perspective in which "the uses and consequences of information technology emerge unpredictably from complex social interactions" (Markus and Robey 1988, 588). A second step is to recognize that the very act of drawing a clear line between (on the one hand) "technology" and (on the other) "the organization" is highly artificial. As Barry pointed out:

To say that a technology can be political is not to denounce it, or condemn it as a political instrument, or to say that its design reflects particular social or economic interests. Technology is not reducible to politics. Nor is to claim that technical devices and artefacts are 'social constructions' or are 'socially shaped': for the social is not something which exists independently of technology. (Barry 2001, 9) 
Thus we find, for example, that the leading network theorist, Castells, proposes that " $[\mathrm{T}]$ he internet is the technological basis for the organizational form of the Information Age: the network" (Castells 2001, 1). If this at first sounds deterministic (i.e. the existence of the internet forces us to switch to network organizations) further reading of Castells shows that this is not his meaning at all. Indeed, he is quite explicit that:

The point of departure of this analysis is that people, institutions, companies and society at large, transform technology, any technology, by appropriating it, by modifying it, by experimenting with it. (Castells 2001, 4)

It follows that there are no easy formulae. Students looking for the big theory that fits all circumstances; popular academics competing for their places on the airport bookstands; textbook authors looking for the boxed half page summary all will be disappointed by this contextuality. For it rules out the generic, global generalizations and the simple arrow diagrams. It insists that "making clear distinctions between the technical and the social is always problematic, because each has elements of the other embedded within it" (Sahay 1997, 235). Many case studies of particular technologies have shown how complex and indeterminate the interactions between the technical, the cultural and the organizational frequently are (e.g. for citizens and politics generally, see Norris 2001; for the police in particular, see Chan 2001). Both technologies and institutional/organizational arrangements "function ... as dependent and independent variables" (Fountain 2001, 12). Exactly the same technology can have very different results when introduced to different social contexts, while, equally, a social context can be significantly changed by the introduction of a new technology (see also Bekkers and Homburg 2005, 9).

A number of different theoretical approaches attempt to deal with the importance of context, but the focus of this paper is not on picking a winning theory but rather on making the general case for the importance of technological change. Relevant context-sensitive theories include, for example, "critical realism" (Pawson and Tilley 1997; Pawson 2002), the evolutionary approach to policy studies (Kay 2006); historical institutionalism (Pollitt and Bouckaert 2009), actor network theory (Latour 2005) and, specific to the study of e-government, "information ecology" (Bekkers and Homburg 2005).

There is one further, crucial element that has not yet been discussed, and that is human initiative, creativity and leadership. Even when a context is favourable for a given mechanism, successful technological change will still require some kind of leadership or, at least, sensible stewardship. Bad management can mess up even a promising set of circumstances, and, occasionally, good management may achieve something against the contextual odds. The successful politician or manager is "in the right place at the right time". This "human factor" (or, more pretentiously, "voli- 
tional conduct" - Barzelay and Gallego 2010, 211) is another reason why the adoption of a given technology does not always produce the same result.

Thus technology, as indicated earlier, is not a separate entity: it is embedded in the social (and political), and vice-versa. Fountain (2001) draws a distinction between what she terms "objective technologies" and "enacted technologies". The former represent the full potential of the particular technology and the latter what it actually gets used for. Thus, for example, "objectively" my PC is capable of many, many things for which I actually never use it, including some which I do not even know how to use it for. The enacted PC is a much more limited, but socially embedded thing than the objective PC. And institutions play a huge role in shaping what is "enacted". Would I have taken up email in the early 1990s if I had not been a dean at a university where the directorate decided to use that as its medium of communication and to pay for staff to be trained and have it installed? Probably not.

\section{Shifts induced by technological change: specifics}

Having discussed the definition of technology, and having briefly considered the relationships between technological change and organizational change, we can now focus more closely on the effects of technological change, envisaging these as shifts across a number of key dimensions. We begin with the fundamentals - time and space - and then move on to other important aspects such as activities and rules, thus gradually building a conceptual framework within which to categorize and analyze the impacts of technological change on public services. In taking this approach, I am building on the much earlier work of Taylor and Bellamy. In a number of publications, they developed the idea of an "information polity" which consisted of several key relationships between stakeholders. My framework is different from theirs, but it partakes of the same concern to ensure that the study of technological change in public administration promotes "engagement with the complexities of the political and social world in which technologies are being adopted" (Bellamy and Taylor 1998, 150). Within each category I try to give examples that illustrate something of the variety and scale of technological effects (always bearing in mind that these are not the deterministic "effects" of impersonal devices and artefacts, but rather the outcomes of interactions between devices and individuals, organizations and practices).

\subsection{Shifts in time}

The most obvious effect here is that, in many (but not all) cases, citizens and public officials alike become accustomed to much faster service than in the pre-digital era. We tap in the details and expect to get a reply almost straight away - certainly for information requests, and often for more interactive contacts also. We also get used to being able to engage with government at any time of day or night - we are no lon- 
ger confined to "office hours", nine to five. This is one factor helping to blur the older dividing lines between "working time" and "leisure" or "private" time. For many, but not all of us, the "pace of life" seems to be speeding up, and the traditional divisions of the calendar are under pressure (Pollitt 2008, 59-63, 180-184). We may fill in our on-line tax form at home on Christmas afternoon or sit in the office emailing our Christmas greetings with electronic cards from the office, confident that, although we are sending them all round the world on 23 December, they will nevertheless arrive "on time". Changes in basic perceptions of time (such as the attenuation of the distinction between "worktime" and "hometime") may seem to be of primarily sociological or even philosophical interest. Yet there is a good deal of research to show that they also have significant consequences for the making, implementation and evaluation of public policies (Pollitt 2008).

In a more direct way, modern technologies simply change the time scale for much administrative work. One development that is much commented upon among older practitioners is the way in which word processing has allowed bureaucracies to produce, multiply and modify documents so much more quickly than in the days of the typing pool. At the top of large public bureaucracies, this can create a maelstrom of paper in which strict rules are needed about the format and labeling of different "editions" of the same document - to avoid chaos and confusion. Alternatively, where record-keeping rules are slack, policy-making can disappear behind a welter of unarchived SMS messages and emails, making it almost impossible to reconstruct the decision-making process for subsequent accountability purposes (Select Committee on a Certain Maritime Incident 2002; Weller 2002)

Technologies have also changed time scales for citizens - with strong implications for their interactions with public authorities. One of the many worrying features of the Hurricane Katrina disaster in New Orleans was the vulnerability of sections of the population to even the shortest interruption to "normal services". "The expectation that federal resources would not be needed for seventy-two to ninety-six hours was disastrously wrong. The scale of the disaster and the vulnerability of the population required a much faster response" (Waugh 2006, 21). In a modern, high-tech, consumer society, many people needed to be able to make daily trips to the supermarket for food and the pharmacy for drugs, not to speak of being metaphorically (and in some cases literally) marooned as soon as their cars would not work or could not make headway on the chronically jammed highways. The Second World War ideology of privation and rationing that led my own parents always to keep "stocks" of almost everything we could possibly need in the cellar had long since disappeared. In effect, many modern households practice "just in time" purchasing, which means that any interruptions in supply have immediate effects.

Yet modern technologies do not all point in the direction of greater speed. There are also paradoxical effects when organizations find themselves "locked in" to major technologies which, although no longer anywhere near optimal, are too com- 
plex or too expensive to change. In their book on digital-era governance, Dunleavy et al. point out how some public administrations are trapped within old "legacy" ICTs, such as the enormous computer systems which in most countries now run social security, healthcare, air traffic control or population registration. "This dynamic can easily create a five- to ten-year 'big bang cycle' approach, in which short-term policy changes are frozen out and almost all change hangs on renewals of major ICT infrastructures" $(2006,27)$. One might also think of the urban motorway - often jammed and heavily polluted, but representing so much investment and operational commitment, both public and private, in a particular transport technology, that it is impossible to change quickly.

\subsection{Shifts in place}

In one adult lifetime, the whereabouts of government has shifted considerably. [I use "government" very loosely here - in the English fashion - to include central and local government and other major public services such as the healthcare, education, social care and police services.] In England, for example, Whitehall is still Whitehall, but since 1960, it has undergone at least four major "deconcentration" exercises, each one intended to shift thousands - tens of thousands - of civil servants out to "the regions". Thus, for example, the central records of birth, marriage and death have moved from Somerset House in central London to Southport in North West Lancashire, my car is licenced in Swansea (Wales), and my English currency is controlled by the Royal Mint at Llantrisant (also Wales), which moved there in 1968 after 900 years or so in London. The latest relocation exercise has moved more than 20,000 civil service jobs out of Greater London since 2004 (Lyons 2004). Such moves are supposed to achieve several objectives: to reduce costs (both buildings and staff are cheaper outside the South East), to improve recruitment (certain types of staff are more easily recruited outside London), to boost employment in areas that suffer from relatively high unemployment and also, it is sometimes claimed, to offer staff a higher "quality of life". Relocations are crucially dependent on the quality of transportation and communication technologies - how long does the train/plane take to get to the capital for meetings with the minister; are there good motorway links; can one use videoconferencing to save time and travel, are there secure, encrypted links for message and data transfer?

One large-scale, widely publicized set of changes has been the closure of small post offices (I use the example of the UK here, but there have also been large numbers of such closures in other countries). In 1979, there were more than 22,000 UK post offices. By early 2009, this number had been reduced to fewer than 12,000, and many still remained under threat. Behind this decline lay a number of factors, but one important one was the decline in postal volumes as more and more communications and transactions shifted to the internet. Even if many post offices clearly lost money, closures on this scale attracted enormous public protest and continuing parliamentary interest and scrutiny (e.g. Business and Enterprise Committee 2009). 
It was frequently pointed out that local post offices had important social and community functions which did not register on their financial accounts. Particularly in rural areas, the closure of the post office sometimes also meant the closure of the last local shop and the loss of a prime meeting place for local residents. The government committed itself to elaborate access criteria (National Audit Office 2009, 16) but even so, the chances that, in my old age, I will be able to walk to my local post office will be less than those for my parents' generation.

In many countries, another highly significant shift has been the disappearance of hundreds of smaller hospitals. Professional logic, financial logic and technological logic have intertwined to produce a concentration of acute services at large hospitals, each with a substantial local, regional or national catchment area (McKee and Healy 2002). Professional logic has demanded the co-location of a critical spread of different specialists on one site, so as to be able to provide an integrated, 24-hour service. Financial logic has argued against the duplication of services in several smaller units, seeking economies of scale and higher intensities of use with respect to overhead services and high cost medical equipment. Expensive new technologies such as MRI scanners or computer-controlled radiographic equipment are beyond small hospitals both financially and in terms of the skilled teams needed to operate them. The overall result, both in England and other European countries, has been the gradual attrition of many small hospitals (For Belgium and England see Pollitt and Bouckaert 2009). As indicated, this shift has been supported by a powerful set of official arguments, but that has not prevented it from being, on the whole, deeply unpopular with the citizenry. Many bitter battles have been fought by local residents to save the smaller local facilities, although only a few of these rearguard actions, in the long run, seem to have been successful.

Some public services, or parts of public services, have moved outside the country altogether. If I had been a student taking UK National Curriculum tests SATs - in 2008, I might have been one of the $1.2 \mathrm{M}$ for whom the important results arrived late or not at all. That would have been because, although the tests were national tests, and although I had taken them in a state school, the organization of the marking had been contracted out to a specialist American educational company - Educational Testing Services - which a subsequent independent inquiry by Lord Sutherland found to carry the biggest responsibility for the technical and logistical failures (Sutherland Inquiry 2008). ETS had declined to submit evidence to the Inquiry, but there was a good deal of evidence available from other parties to show that the systems installed by ETS had been inadequately tested and were subject to cumulative failure. The government subsequently terminated the ETS contract.

Yet physical relocations and contracting-out have not necessarily been the most striking place changes, at least from the perspective of an individual citizen. Even more noticeable has been the recent shift to web-based systems of citizen/state interaction for many if not most of the public agencies with which the average citi- 
zen has to deal. Thus my tax returns, driving licence application, passport renewal and US visa application - all these and many more no longer require my physical presence in a public office anywhere at all. I can deal with it all from home, or from my office, or from my laptop on a train, or from an internet café in the high street.

As soon as services can be provided mainly or exclusively online rather than face-to-face, there is a powerful fiscal logic to moving offices away from expensive locations and re-siting in cheaper accommodation. Then there is the question of databases. Huge databases are required to support major public services such as social security or healthcare, but when these are computerized, they can be sited almost anywhere. As indicated earlier, when "family records" meant large paper ledgers, they needed to be somewhere central, but once they can be put online, who knows where the electronic storage devices may be? Further, the advent of mobile communication devices means that all sorts of activities which would once have required an office somewhere are no longer fixed in that way. Mobile data terminals in police cars can immediately access a growing range of national databases, giving a single car access to far more quick information than a whole police station would have had a generation ago (Sørensen and Pica 2005).

One interesting feature of the general shift to net-based services is that the actual physical location of many government offices has now virtually disappeared. "Contact us", the websites say, but when a citizen hits that button, $s /$ he often gets not a (postal) street address, but a telephone number and an email enquiries address. Postal correspondence, it seems, is actively discouraged, no doubt for reasons of cost and efficiency. Indeed, one of the recently discussed ideal models for e-government has been the "single portal" - a sole electronic window for the whole of government. In this arrangement, the entire government (or large sections of it) appear as though they were a unity, a single agency. But this is a virtual agency, behind which the "real" organizations are as multifarious as ever - and are certainly not in one place.

\subsection{Changes in tasks/activities}

We begin this section with the basic observation that often a change in technology may alter the range of tasks which those providing the service are called upon to perform. This is trivially true in the case of, say, the arrival of police patrol cars in the 1960s, when, within a space of years, virtually all police officers had to learn how to drive, or in the 1980s and '90s, when most public officials stopped sending their letters to the typing pool and started tapping keyboards themselves. However, it is also true in a more profound sense. Consider the advent of forensic DNA testing, photonics and other forms of high-tech crime scene investigation (now glorified in numerous TV series). These transformed the tasks to be undertaken at the crime scene and, to a significant extent, who was going to undertake them. Now the generalist uniformed police officer, or even CID officer, has to share the limelight with 
an array of specialists, each deploying their own particular technologies (see, e.g., http:www.npia.police.uk/, accessed February 2010)

Few would have expected that the invention of the humble home burglar alarm would have much effect on the activities of the police. Yet, in 1996, an Audit Commission study of English and Welsh police forces noted that:

The activation of an intruder alarm is treated as an immediate response call because it may mean that a crime is in progress, but the vast majority are in fact false alarms. This is a particular concern to police managers seeking to make the best use of their officers' time, and ACPO [Association of Chief Police Officers] recently reviewed its policy of attending alarms that repeatedly malfunction. In 19941.1 million activations of remote-signalling intruder alarms were checked by the police, typically by a doublecrewed response unit. Some $92 \%$ of these activations - just over one million - were false alarms. It takes between 15 and 40 minutes to check a false alarm and thus the minimum opportunity cost to the police was in the region of 500,000 hours. (Audit Commission 1996, 25)

This is one part - but only one small part - of the long-running story of "bobbies on the beat" (police officers walking the streets). Public opinion surveys consistently show that a majority of the population place a high value on the visibility of police on patrol - uniforms walking past. However, for a whole variety of reasons - including distractions from malfunctioning intruder alarms -, satisfying this public wish is problematic in several ways. First, in terms of catching criminals, deploying police on general foot patrol is not at all effective. Second, as the police force itself has become more specialized, the number of police needed for these specialized duties (computer crime, anti-terrorist squads, child protection, management and planning and so on) has grown. When the Audit Commission did its study in 1996, it estimated that in a typical police force of 2,500 officers, only 125 constables would actually be on the street at any one time (Audit Commission 1996, 9-11). More recently, we find that the police as a whole are spending more and more time in front of computer screens and less and less walking the streets - or, at least, that is the impression of both Belgian and English senior police officers questioned during recent research (Pollitt and Bouckaert 2009). Official figures showed that by 2007-2008, English police officers spent only $13.8 \%$ of their time on patrol (Whitehead 2009,1 ).

Our example of the post office network also displays clear interactions between changing technologies and changing tasks. In the UK, most state pensions and benefits used to be handed out, in cash, at post offices. Over the years, these payments both became electronic and mostly migrated to the commercial banks. Car tax discs were another source of post office business, but most of these are now 
obtained online. The attempt to save the post office network has included the development of new forms of financial service and the substitution of mobile post offices for fixed buildings in some rural areas (National Audit Office 2009).

However, the picture is not simply that of new technologies "raising the game" and requiring new breeds of expert. It is more complicated than that:

The aggregation of tasks, in which operators are given more responsibilities ... using computer-based information processing and 'decision support tools', is often described as 'empowerment' or 'job enlargement'... But the range of potential choices the 'empowered' operator can make is often limited by the software, thus embedding control formerly exercised by supervisors. Moreover, an operator's decisions are visible to those in charge, and the system may automatically report deviations from standard procedures (Fountain 2001, 37-38).

Thus, for example, Belgian police who consult certain national databases now know that their identities are recorded each time they access the data and that a new set of tasks has been created around monitoring the patterns of access of the many police officers using these sources. This can be a powerful tool for monitoring and accountability. In the event of subsequent enquiries, it can show if an investigating officer has failed to look up things s/he should have looked up. It can also show if officers have been accessing data that does not appear relevant to their responsibilities - possibly for personal or even corrupt motives. New posts have been created with the responsibility of monitoring these patterns of access for accountability purposes.

Perhaps one of the most important aspects of task-changing is to be found in the role of ICTs in achieving "joined-up government" or "cross-cutting services" (6, 2004). ICTs hold out the potential for various kinds of "joining up", ranging from putting a new joint face on related services (a single portal or gate on the net) to the progressive linking-up of back-office operations and databases (Brown 2007; Kernaghan 2007). One-stop shops or single windows on the Web have been a growing trend in many countries and seem to be popular with the citizens and firms that use them. Almost by definition, they create new tasks, because they require public servants to bring together, standardize and co-ordinate activities that were previously separate. To borrow the jargon, they require boundary-spanning skills.

\subsection{Changes in rules}

As first-year public administration students are usually taught, a prime characteristic of public sector bureaucracies is that they are rule-following organizations. Some of those rules are embodied in hard law, some in "soft law", and some are merely internal administrative procedures. Quite often, new technologies enable new ways 
of doing things, and the new ways of doing things fit very uncomfortably with the old rules. So the old rules have to be changed, and new rules substituted.

Record-keeping is a very basic requirement for public bureaucracies, and they commonly have many rules concerning what records count as "official", how they are to be kept and who is to have access to them. The advent of new communications technologies - especially email, SMS and mobile phone conversations - have led to reconsiderations of these rules in many countries. In some cases, major controversies have arisen over the lack of order in record-keeping, due partly to the multiplication of media being used (Weller 2002, 89; Select Committee on a Certain Maritime Incident 2002, ch. 7). In a number of countries, weighty reports have been produced proposing new rules for record-keeping in the digital age (Pollitt 2009).

In the case of the police and security services, there have been and continue to be many detailed rule changes in many countries concerning police access to both computer systems and mobile phone records. In Belgium, it was the infamous Dutroux pedophile case that had been instrumental in persuading politicians to change the rules and allow the construction of a national criminal database. In the UK, the 7/7 London terrorist attacks stimulated the government to introduce various pieces of new legislation incorporating new rules for the police and security services.

Rule changes may affect even the most personal aspects of our identities. Since 1974, the Finnish Population Register has issued each newly born Finnish resident with a personal identity code (PIC). This was a centralized computerized system that was generally regarded as ahead of its time. The PIC now serves a variety of purposes, including social security and pension entitlements. One of the characters in the code indicates whether the individual is female (even number) or male (odd). Recently, however, advances in medical technology have made possible more sex changes. This has led to a small number of cases in which gender-reassigned citizens want their PICs changed - against existing rules that the PIC was an unchanging, life-long identifier. More generally, several studies have shown how IT developments can affect basic aspects of citizenship and identity (e.g. Taylor et al, 2007, 2009).

More generally, the creation of more and more web-based public services, onestop-shops, multi-organizational portals and gateways and other kinds of "joining up" inevitably leads to the questioning of pre-existing jurisdictional boundaries between organizations and of traditional lines of accountability (Fountain 2001). New linkages and new inter-relationships rub up against old rules defining organizational borders. The blurring and redefining of jurisdictional borderlines may not have attracted much public attention - it is often seen as a purely technical issue but in fact it can easily have significant implications for the practice of "separation of powers" or federalism or bureaucratic accountability (Bekkers 2000). 


\subsection{Effects on resource flows}

Technological change affects flows of resources in both public and private sectors. Technologies are bought and sold. They can make profits for those who sell or maintain them, and they can also make savings for public sector organizations which use them to achieve higher levels of efficiency.

There is perhaps a tendency for some scholars to become so entranced with the technological possibilities and implications of new devices that they forget the fundamental importance of the economics of technological development. New technologies are, however, big business. Advanced industrial states typically spend over $1 \%$ of their GDPs on public-sector information technology alone - a very substantial resource flow (Dunleavy et al. 2006, 1). So one prominent actor in the dramas of change is usually the contractor or supplier and, as Dunleavy et al. have shown, governments have become increasingly - sometimes dangerously - reliant on the big corporations of the global IT industry. Some of the stories of computer consultancies continuing to win large government contracts after being wholly or partially responsible for expensive failures make for uncomfortable reading (Craig 2006; Dunleavy et al. 2006).

There are reasons why large scale government IT contracting is especially difficult - and sometimes very profitable for the contractors (Borins et al. 2007, 29-30). To begin with, the systems are sometimes very large - social security or police or identity systems to cover whole populations, supporting millions of daily transactions. Then there is the tendency (regretted by some commentators) for governments to have "special requirements" in terms of systems that must be able to be used by anyone, including the most unlearned, and which must incorporate very high standards of security and privacy. Such tailor-made systems are understandably more expensive than off-the shelf, standardized software. Size plus "specialness" equals complexity, and projects of this kind are so complex that often only a few (usually multinational) companies can realistically bid for them. What is more, once such a project is underway, it is extraordinarily difficult to back out or change contractual horses. All these factors point towards the possibility of big money and substantial profits for the winning companies.

From the perspective of public authorities, however, new technologies may hold the promise of savings rather than profits. Governments, always under budgetary pressures, are often drawn to this promise of expenditure reductions. "Cheaper" is often just as important as "faster" or "better". And it is true that there are many cases where a new technology enables savings to be made. If a new technology enables staff to complete a given task more quickly, the management can either do more tasks for the same money or possibly reduce the size of the workforce (thereby making budget savings) without reducing the level of service provided. A recent example would be the Lantern system of mobile identification, tested experimentally by the English police. It enables on-foot police to check identification databases and 
therefore avoid having to take suspects back to the station unnecessarily. On the trial, Lantern saved an average of 87 minutes per case in $50 \%$ of the cases in which it was deployed (National Policing Improvement Agency, http://www.npia.police. uk, accessed January 2010)

Unfortunately there are two rather important qualifications to the expenditure-saving potential of new technologies. The first is that making savings later on usually requires investment up-front. With some of the biggest systems (e.g. in social security; healthcare), the initial investment is very large and the period before the innovations pay for themselves and begin to save is quite extended. These initial investments are particularly vulnerable in times of fiscal stress (Borins 2007). When ministries of finance are looking for cuts, expensive future projects, as yet unknown to citizens, become natural targets. It is politically less painful to postpone or cancel a big computer project than to take existing benefits or programmes away from citizens.

The second qualification is that, even when the investments are made, money is not always saved; indeed, it may be lost. Internationally, the list of major government IT projects which have either failed to work or worked only after enormous, unforeseen budget increases is distressingly long (see, e.g. Craig 2006; Dunleavy et al. 2006, 172-173; National Audit Office 2000). There are many difficulties for governments in managing large-scale IT (or other technological) projects, including lack of internal expertise (the contractors pay higher salaries and are able to commandeer most of the real "talent"), poorly-designed contracts, constant changes of specification coming from the political or senior official level and the hard-to-avoid risks of being locked into an extended piece of technological development where, after a certain point, it is more expensive to back out than to stay in, even with rising costs and under-performing technology.

\subsection{Effects on individuals}

Since changing technologies change tasks, it is hardly surprising that they eventually change the public officials who perform those tasks. Less obviously, it can argued that they also help to change the citizens who need or want to access state services. Let us begin with the officials.

As tasks become more complex, higher levels of education and training may be required of personnel - this would be true, for example, of police, nurses and school teachers, if looked at over the past half century. Interestingly, in each case, as the police officer/nurse/teacher has become a more highly trained, expensive item, new, less trained, cheaper staff have emerged as ancillaries (at least in the UK) - Police Community Support Officers, Nursing Assistants and Learning Support Assistants. In parallel with this, each profession has also become more dependent on "experts" from outside their cadre altogether. This is visible in medicine, with the burgeoning variety of para-medical specialists, but perhaps the most spectacular 
case is the police, who are increasingly reliant on a range of experts in the various diagnostic and surveillance technologies which they now routinely employ.

Staying with the police for a moment, we can also observe that, thanks to burgeoning communications and surveillance technologies, the control room has become a more important location within the police service. While researching the police in mid 2007, I was shown round the operations room and CCTV centre for the Brighton police force (Pollitt and Bouckaert 2009). Here, high up in a tower block in central Brighton, mainly civilian staff were able to watch many of Brighton's streets on CCTV, simultaneously communicating with foot and vehicle patrols to direct them to any observed incidents. Already, the screens incorporated automatic vehicle recognition software that signaled as soon as any vehicle with a registration plate logged on the Police National Computer as being of interest passed a camera. Under the overall direction of a Chief Superintendent, civilian staff sat in a semidarkened room, in effect moving police officers around the town like pieces on a chess board. Additionally, in the event of a fight or assault, the control room had a visual record against which the statements and claims both of involved citizens and of the police themselves could be checked. Not that CCTV cameras always work or are well-maintained. And not that would-be criminals are passive pawns in this new system of surveillance: they have developed a variety of ways of defeating the cameras, ranging from wearing hoods to breaking the cameras (as any devotee of the wonderful Baltimore TV series The Wire will remember) to redirecting their activities to other parts of town, where the cameras do not pry (see also Nunn 2001). Nevertheless this brief portrait suggested several technologically facilitated transitions for the individuals concerned: police on patrol being monitored and to some extent re-directed by civilian staff sitting a mile away in a control room and citizens in public places constantly exposed to the gaze of CCTV. Furthermore, at a higher level, top police managers could subsequently be held to account against very detailed electronic records of exactly what decisions had been made at what time and on what evidence in "their" control room.

Technological change may therefore lead to changes in who is recruited to public service jobs. This is not only a matter of the civilianization of certain aspects of police activities. When modern ICTs permit functions to be "deconcentrated" from the capital to regional cities or even rural locations, one result is that the relocated function then draws on the local labour market, not the one in the capital. Indeed, one of the express aims of such geographical moves is to profit from the lower wage levels and higher availability of certain skills in less "overheated" labour markets (Lyons 2004).

A further point is that certain types of public officials who used to be very common have now virtually disappeared - the typist, the filing clerk and even the conventional secretary. Typically only very senior staff now qualify for secretaries, 
and they are called "executive assistants", or something like that, rather than secretaries, and they perform a changed mix of functions.

Now we turn to changes for citizens/public service users. Most obviously, as discussed above, the ability to access the internet is now needed if a citizen is going to obtain a wide range of public services, at least in a convenient way. Even if the "digital divide" is said to be lessening (Castells 2010, xxvv), it still exists, which means that some sections of the population are increasingly disadvantaged. Others, however, are positively advantaged. For example, those wholly or partly confined to their homes through sickness or disability no longer need to find other people to represent them in many of their dealings with central and local governments. They can do it themselves, from their home internet connection. They are - to use a frequently abused term - "empowered". So are those UK citizens who need urgent medical or nursing advice but who, for whatever reason, cannot get to a doctor's office and instead access the very popular "NHS Direct" website.

Less obviously, the rapid spread of remote surveillance devices, especially closed-circuit television (CCTV) - both public and private - has changed the way many people feel about being in public spaces:

Emotionally there is a big difference between being looked at by someone directly and being looked at through the lens of a surveillance camera. The variety of feelings surveillance evokes is enormous: those being watched may feel guilty for no reason, embarrassed or uneasy, irritated or angry, or fearful; they may also feel secure and safe (Koskela 2000, 257)

Some citizens react to remote surveillance technologies with actions intended to defeat them. These can range from simply wearing a hood or mask to buying devices that will warn their owners when and where they come under surveillance or will even interfere with the normal working of the surveillance technology. There is a never-ending technological race between the police and the criminals - with the expenditures of both sides benefiting those companies who develop the relevant technologies.

How far does the use of the internet actually change the level and/or type of "civic engagement" undertaken by citizens (Norris 2001)?. One "cyberoptimist" position is that the amazing new possibilities of the internet will encourage all sorts of people to mobilize and participate in public affairs in new ways. A more cyberskeptic view is that "online resources will be used primarily for reinforcement by those citizens who are already active and well-connected by traditional channels ..." (Norris 2001, 218). In this scenario, the internet facilitates a deepening of the divide between the civically engaged and the civically excluded or disenchanted. Some evidence can be deployed on both sides of this argument, and it is also possible that there is a temporal sequence, with reinforcement being the predominant 
response in the early phases of e-government and more widespread and creative citizen involvement gradually accumulating as systems mature and the younger, internet-savvy generations grow up. One recent piece of U.S. research concluded that the main effects to date had been to reinforce pre-existing patterns of civic engagement, but that it was possible (no more) that the recently ballooning social networking tools could come to support the discussion of public-affairs issues across a wider constituency than would previously have engaged with this agenda (Smith et al. 2009).

\section{Adding actors to effects}

The foregoing discussion suggests that the effects of changing technologies may usefully be analyzed under a number of headings, where each heading concerns a particular type of impact (on tasks, on resources, etc.). However, it is also clear that a particular effect impacts differently on different actors in the process. Thus (for example) a new ICT may give a faster 24/7 service to citizens who can use the internet, while at the same time leading to job losses for staff and to a "second-class service" for users on the wrong side of the "digital divide". Therefore, if one wishes to use the categories developed here for constructing an analytic framework, then we need a second dimension that distinguishes, for each type of effect, between the main public administration actors. Table 1 (below) takes a first step in this direction by plotting the main actors along the horizontal axis, while the types of effect are shown on the vertical axis. Of course different classifications of actors can be made for different purposes - the one shown here is simply a conventional listing of the main "interests" involved in providing a major public service such as healthcare, education or public transport. This dimension merits much more discussion, but that must await another paper rather than this one.

The most important point is that most technological change usually generates effects in many of these cells, not just in one or two. Therefore to focus on only one or two of them may be to miss something important about the "big picture". 
Table 1

A matrix of the effects of technological change and the actors involved

\begin{tabular}{|c|c|c|c|c|c|}
\hline 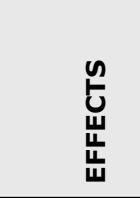 & 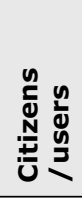 & 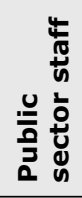 & 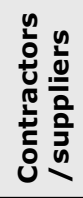 & 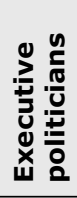 & 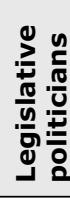 \\
\hline \multicolumn{6}{|l|}{ Time } \\
\hline \multicolumn{6}{|l|}{ Place } \\
\hline \multicolumn{6}{|c|}{ Task/activity } \\
\hline \multicolumn{6}{|l|}{ Rules } \\
\hline \multicolumn{6}{|l|}{ Resources } \\
\hline People & & & & & \\
\hline
\end{tabular}

\section{Conclusions}

The paper has made the argument that technologies - understood as devices, associated practices, and the norms and meanings these generate - have a pervasive but hitherto largely unacknowledged influence on public administration. Many examples have been offered, and it would be easy to offer many more. These include, but go well beyond, the impacts of contemporary ICTs. Technological changes influence the time and place at which citizens interact with government, the nature of public-service tasks, the rules that are supposed to regulate public sector decisionmaking, resource flows (including profits) and, last but not least, the kinds of people we need to employ in the public sector and, ultimately, the kind of citizens we are able to be.

In sum, technological change has an enormous influence on public management. It is too important - too central to our field - to be left to a few specialists. It deserves a more central position in our studies, and hopefully the framework proposed in this paper may be of some assistance in facilitating the required shift of academic attention.

\section{Acknowledgements}

I am grateful to William Webster (Stirling University) for his perceptive comments on an earlier version of this paper. 


\section{References}

6, P. 2004. "Joined-up Government in the Western World in Comparative Perspective: A Preliminary Literature Review and Exploration." Journal of Public Administration Research and Theory 14 (1), 103-138.

Arthur, W. B. 2009. The Nature of Technology: What it is and how it Evolves. New York: Free Press.

Audit Commission. 1996. Streetwise: Effective Police Patrol. London: HMSO.

Barry, A. 2001. Political Machines: Governing a Technological Society. London and New York: Athlone Press.

Barzelay, M. and R. Gallego. 2010. "The Comparative Historical Analyses of Public Management Policy Cycles in France, Italy and Spain: Symposium Introduction." Governance 23 (2), 297-307.

Bekkers, V. 2000. "Information and Communication Technology and the Redefinition of the Functional and Normative Boundaries of Government." In O. Van Heffen et al. (eds). Governance in Modern Society. Dordrecht: Kluwer, 257-278.

Bekkers, V. and V. Homburg (eds). 2005. The Information Ecology of e-Government. Amsterdam: IOS Press.

Bellamy, C. and J. A. Taylor. 1998. Governing in the Information Age. Buckingham: Open University Press.

Borins, S. 2007. "What Keeps a CIO Awake at Night? Evidence from the Ontario Government." In S. Borins, K. Kernaghan, D. Brown, N. Bontis, P. 6 and F. Thompson. Digital State at the Leading Edge. Toronto: University of Toronto Press, 69-101.

Borins, S., K. Kernaghan, D. Brown, N. Bontis, P. 6 and F. Thompson. 2007. Digital State at the Leading Edge. Toronto: University of Toronto Press.

Bovaird, T. and E. Löffler. 2009. Public Management and Governance. $2^{\text {nd }}$ edn. London and New York: Routledge/Taylor and Francis.

Brown, D. 2007. "The Government of Canada: Government on-line and CitizenCentred Service." In S. Borins, K. Kernaghan, D. Brown, N. Bontis, P. 6 and F. Thompson. Digital State at the Leading Edge. Toronto: University of Toronto Press, 37-68.

Business and Enterprise Committee. 2009. Eighth Report, Session 2008-09: Post Offices - Securing their Future. 23 June. Available at http://www.publications. parliament.uk/pa/cm200809/cmberr/371/37102.htm (Accessed 11 September 2009). 
Castells, M. 2010. The Rise of the Network Society. $2^{\text {nd }}$ edn. Chichester, West Sussex: Wiley-Blackwell.

Castells, M. 2001. The Internet Galaxy: Reflections on the Internet, Business, and Society. Oxford: Oxford University Press.

Chan, J. 2001. "The Technological Game: How Information Technology is Transforming Police Practice." Criminology and Criminal Justice 1 (2), 139-159.

Christensen, T. and P. Lægreid. 2007. Transcending New Public Management: The Transformations of Public Sector Reforms. Aldershot: Ashgate.

Craig, D. 2006. Plundering the Public Sector: How New Labour are Letting Consultants Run off with $€ 70$ Billion of our Money. London: Constable.

Dunleavy, P., H. Margetts, S. Bastow and J. Tinkler. 2006. Digital Era Governance: IT Corporations, the State and e-Government. Oxford: Oxford University Press.

Ferlie, E.; L. Lynn, Jr. and C. Pollitt (eds). 2005. The Oxford Handbook of Public Management. Oxford: Oxford University Press.

Fountain, J. 2001. Building the Virtual State: Information Technology and Institutional Change. Washington DC: Brookings Institution.

Graham, S. 1994. Free-nets and the Politics of Community in Electronic Networks.

Geels, F. 2004. "From Sectoral Systems of Innovation to Socio-Technical Systems: Insights about Dynamics and Change from Sociology and Institutional Theory." Research Policy 33, 897-920.

Hood, C. 1998. The Art of the State: Culture, Rhetoric and Public Management. Oxford: Oxford University Press.

Hood, C. and H. Margetts. 2010. "Cyber-Bureaucracy: If it is so Central to Public Administration, why is it so Ghetto-ized?" In J. Pierre and P. Ingraham (eds). Comparative Administrative Change and Reform: Lessons Learned. Montreal and Kingston, McGill-Queen's University Press, 114-138.

Kay, A. 2006. The Dynamics of Public Policy: Theory and Evidence. Cheltenham: Edward Elgar.

Kernaghan, K. 2007. "Beyond Bubble-Gum and Goodwill: Integrating Service Delivery." In S. Borins, K. Kernaghan, D. Brown, N. Bontis, P. 6 and F. Thompson. Digital State at the Leading Edge. Toronto: University of Toronto Press, 102-136.

Kickert, W. (ed.). 2008. The Study of Public Management in Europe and the US. Abingdon: Routledge/Taylor and Francis.

Koskela, H. 2000. "The Gaze without Eyes: Video-Surveillance and the Changing Nature of Urban Space." Progress in Human Geography 24 (2), 243-265.

Latour, B. 2005. Reassembling the Social. Oxford: Oxford University Press. 
Lips, M. and T. Schuppan. 2009. Editorial: Transforming e-Government Knowledge through Public Management Research. Public Management Review 11 (6), 739-749.

Lyons, M. 2004. Well Placed to Deliver: Shaping the Pattern of Government Service. Independent Review of Public Sector Relocation. London: H. M. Treasury.

McKee, M. and J. Healy (eds). 2002. Hospitals in a Changing Europe. Buckingham: Open University Press.

Markus, M. and D. Robey. 1988. "Information Technology and Organizational Change: Causal Structure in Theory and Research." Management Science 34 (5), 583-609.

National Audit Office 2009. Department for Business, Enterprise and Regulatory Reform: Oversight of the Post Office Network Change Programme. HC 558, Session 2008-2009. Norwich: The Stationary Office.

National Audit Office 2000. The Cancellation of the Benefits Payments Card Project. HC 857, Session 1999-2000. London: The Stationary Office.

Norris, P. 2001. Digital Divide: Civic Engagement, Information Poverty and the Internet Worldwide. Cambridge: Cambridge University Press.

Nunn, S. 2001. "Cities, Space, and the New World of Urban Law Enforcement Technologies." Journal of Urban Affairs 23 (34), 259-278.

Osborne, S. (ed.). 2010. The New Public Governance? London and New York: Routledge/Taylor and Francis.

Pawson, R. 2002. "Evidence and Policy and Naming and Shaming." Policy Studies $23(3 / 4), 211-230$.

Pawson, R. and N. Tilley. 1997. Realistic Evaluation. London: Sage.

Pollitt, C. 2009. "Bureaucracies Remember, Post-Bureaucratic Organizations Forget?” Public Administration 87 (2), 198-218.

Pollitt, C. 2008. Time, Policy, Management: Governing with the Past. Oxford: Oxford University Press.

Pollitt, C. and G. Bouckaert. 2009. Continuity and Change in Public Policy and Management. Cheltenham: Edward Elgar.

Pollitt, C. and G. Bouckaert. 2004. Public Management Reform: A Comparative Analysis. $2^{\text {nd }}$ edn. Oxford: Oxford University Press.

Pollitt, C. and E. Op de Beeck. 2010. "Hyper-Stability in an Age of Hyper-Innovation: A Comparative Case Study." Public Policy and Administration 25 (4) (in press).

Sahay, S. 1997. "Implementation of Information Technology: A Space-Time Perspective." Organization Studies 18 (2), 229-260. 
Select Committee on a Certain Maritime Incident. 2002. Report. Canberra: Senate Printing Unit, October.

Smith, A., K. Schlozman, S. Verba and H. Brady. 2009. The Internet and Civic Engagement. Pew Internet. September 2009. Available at http://www.pewinternet.org/ (Accessed 3 February 2010).

Snellen, I. and W. Van de Donk (eds). 1998. Public Administration in an Information Age: A Handbook. Amsterdam: IOS Press.

Sørensen, C. and D. Pica. 2005. "Tales from the Police: Rhythms of Interaction with Mobile Technologies.” Information and Organization 15, 125-149.

Sutherland Inquiry. 2008. An Independent Inquiry into the Delivery of the National Curriculum Tests in 2008. Report to Ofqual and the Secretary of State for Children, Schools and Families. HC62. 16 December. London: The Stationary Office.

Taylor, J., M. Lips and J. Organ. 2009. "Identification Practices in Government: Citizen Surveillance and the Quest for Public Service Improvement." Identity in the Information Society 1 (1), 135-154.

Taylor, J., M. Lips and J. Organ. 2007. "Information-Intensive Government and the Layering and Sorting of Citizenship." Public Money and Management 27 (2), $161-164$.

Thompson, F. and L. Jones. 2008. "Reaping the Advantages of Information and Modern Technology: Moving from Bureaucracy to Hyperarchy and Netcentricity." International Public Management Review 9 (1), 148-192.

Waugh, W. 2006. “The Political Costs of Failure in the Katrina and Rita Disasters." Annals of the American Academy of Political and Social Science 604, 10-25.

Weller, P. 2002. Don't Tell the Prime Minister. Melbourne: Scribe Publications.

Whitehead, T. 2009. "Bobbies on Beat for Just 6 Hours a Week." The Daily Telegraph, 3 October, 1.

Winner, L. 1986. The Whale and the Reactor: A Search for Limits in an Age of High Technology. Chicago and London: University of Chicago Press. 